\title{
Case Note: Federal Income Tax Consequences of Liquidating an Affiliated Subsidiary into its Parent
}

\author{
Valeriya Avdeev \\ Associate Professor \\ Dept. of Accounting and Law \\ Cotsakos College of Business \\ 1600 Valley Road, Room 4077 \\ Wayne, NJ 07470 \\ Email: avdeevv [AT] wpunj.edu
}

\begin{abstract}
This case note discusses federal income tax consequences to members of XYZ, Inc. Parent consolidated group resulting from a taxable liquidation of ABC, Inc. Subsidiary into XYZ, Inc. domestic Parent.
\end{abstract}

Keywords--- Parent corporation, subsidiary corporation, liquidation, merger, taxation, Internal Revenue Code

\section{Relevant Facts}

Parent purchased all of the stock of Subsidiary on October 1, 2008. Both Parent and Subsidiary are part of the federal consolidated return filing with XYZ, Inc. ("Parent Holding Company" or "Parent Company"). From October 1, 2008 through December 31, 2008, Subsidiary had \$1.3M of taxable losses. Subsidiary's loss for 2008 taxable year was fully absorbed upon filing of the consolidated return for federal income tax purposes.

To sustain Subsidiary's operations, Parent Company made a loan of $\$ 0.9 \mathrm{M}$ to the Subsidiary. Even so, Subsidiary was liquidated into the Parent on October 1, 2009. From January 1, 2009 through September 31, 2009, Subsidiary Corporation had $\$ 2.3 \mathrm{M}$ of taxable losses.

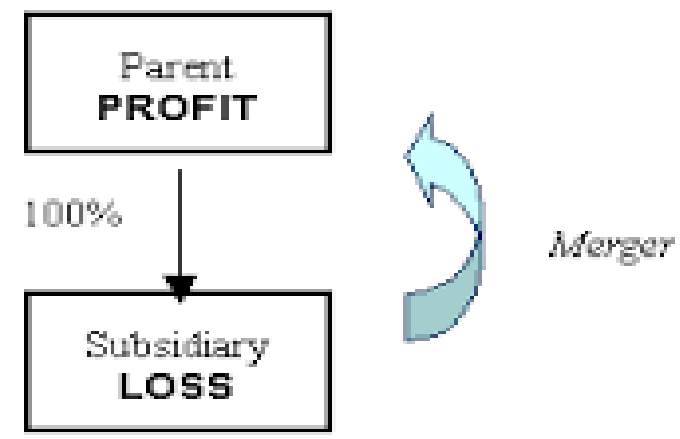

Parties’ Federal Tax Consequences Upon Liquidation

At the time of liquidation, Subsidiary was insolvent to the extent that its liabilities exceeded the gross fair market value of its assets, both calculated immediately before the liquidation. As such, Section 332 of the Internal Revenue Code did not apply to the Subsidiary's liquidation and such transaction was taxable under Section 331.

At the time of Subsidiary's liquidation, the $\$ 0.9 \mathrm{M}$ loan from Parent to Subsidiary was deemed satisfied, even though not paid. As the result, Subsidiary recognized $\$ 0.9 \mathrm{M}$ as cancelation of indebtedness income, which was included in Subsidiary's ordinary income on 2009 tax return.

Since Subsidiary's loan was extinguished for no consideration, Parent Company will have a corresponding bad debt expense for the loan to Subsidiary, to the extent that all of the requirements for claiming bad expense between related parties are satisfied. Upon liquidation and by operation of state law, Parent assumed the $\$ 0.9 \mathrm{M}$ loan and became the new obligor responsible for the repayment of the loan to the global Parent. 
Since Subsidiary was insolvent, the $\$ 0.9 \mathrm{M}$ loan was transferred to domestic Parent for less than the face amount and, thus, will be subject to the original issue discount ("OID") rules. For as long as the loan remains unpaid, domestic Parent would be allowed to amortize the amount of the OID as a deductible expense over the life of the instrument.

The Parent Company, on the other hand, would have to include a corresponding OID into income. When domestic Parent pays the $\$ 0.9 \mathrm{M}$ to the global Parent in satisfaction of the debt, domestic Parent will have a corresponding expense deduction and the global Parent will have an equivalent income inclusion.

Pursuant to IRC Section 336, Subsidiary will have to recognize gain or loss on the distribution of property to domestic Parent pursuant to its liquidation. However, since Subsidiary was insolvent at the time of its liquidation and it was a service business, Subsidiary did not own any property items that had appreciated substantially from the time of domestic Parent's purchase of Subsidiary. As such, for purposes of this case note, an assumption is made that Subsidiary did not recognize any gain or loss upon liquidation under Section 336.

Under Treasury Regulation $\S 1.1502-32$, domestic Parent's basis in JGT will have to be adjusted to reflect Subsidiary's distributions and Subsidiary's items of income, gain, deduction, and loss for the period when Subsidiary was still a member of the consolidated group.

Pursuant to the regulations, every permanent book-to-tax difference will adjust domestic Parent's basis in Subsidiary for both periods covering from the date of purchase of the Subsidiary, October 1, 2008 through December 31, 2008 and from January 1, 2009 through the date of liquidation, September 30, 2009. Cancelation of indebtedness income will also have to be taken into account as an adjusting item.

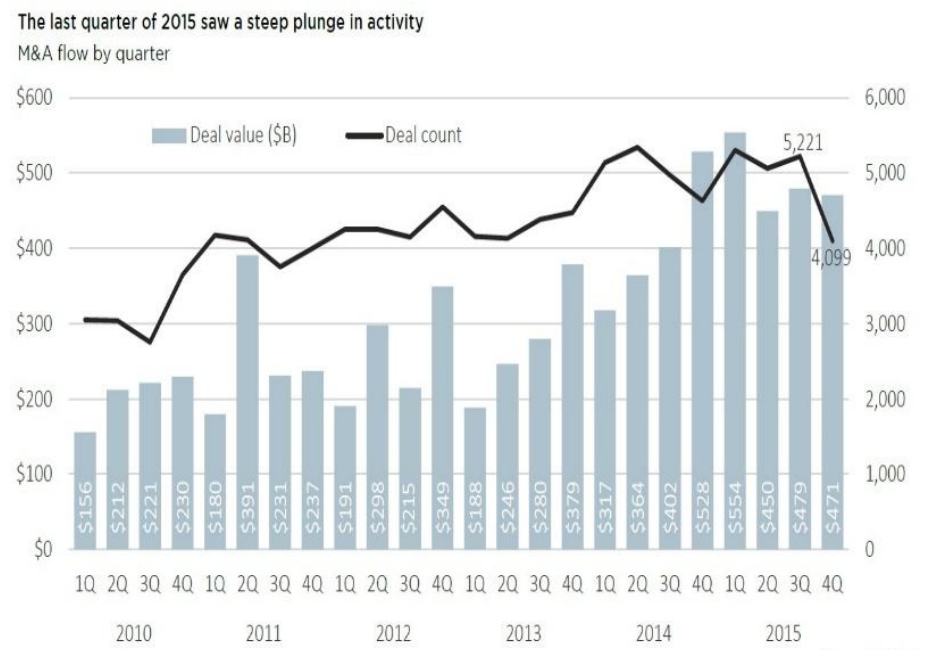

Since domestic Parent has a positive basis in Subsidiary after the necessary Section 1502 basis adjustments, domestic Parent can take a worthless stock deduction under Section 165, equal to amount realized ${ }^{1}$ reduced by domestic Parent's adjusted basis in Subsidiary. Furthermore, a domestic corporation may claim an ordinary loss for worthless stock of an affiliated corporation ${ }^{2}$.

A subsidiary is considered affiliated if both the ownership test and the gross receipts test are satisfied. ${ }^{3}$ Clearly, the ownership test is satisfied since Subsidiary was wholly owned by domestic Parent. ${ }^{4}$

\footnotetext{
${ }^{1}$ Since JGT was insolvent at the time of its liquidation, the amount realized is zero.

${ }^{2}$ I.R.C. $\$ 165(\mathrm{~g})(3)$.

${ }^{3} I d$.

${ }^{4} I d$.
} 


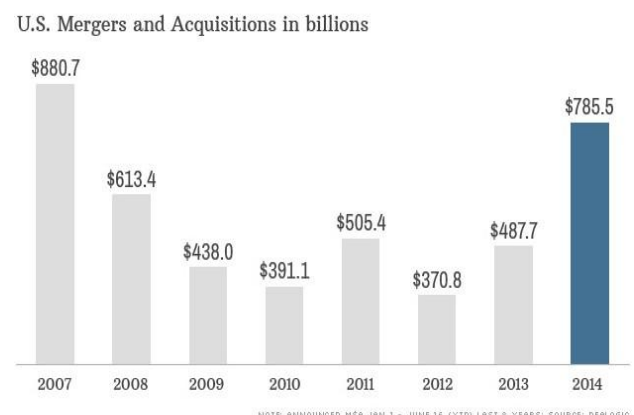

Furthermore, the gross receipts test is satisfied if more than 90 percent of Subsidiary's aggregate gross receipts for all tax years when Subsidiary was in existence were from sources other than royalties, rents, dividends, interest, annuities, or gains from sales or exchanges of stock or securities. ${ }^{5}$

Since Subsidiary was a service business organized to provide advertising and consulting services, the majority of its gross receipts were derived from sale of such services. Thus, gross receipts test is also satisfied and domestic Parent can claim a worthless stock deduction under Section $165(\mathrm{~g})(3) .{ }^{6}$ Such loss will be considered ordinary for federal income tax purposes. ${ }^{7}$

Finally, if global Parent consolidated group were to have a loss for the year-ending December 31, 2009, Subsidiary's portion of that loss would be disallowed, since its liquidation was a taxable transaction. ${ }^{8}$

\footnotetext{
${ }^{5} I d$.

${ }^{6} I d$.

${ }^{7} I d$.

${ }^{8} I d$.
} 